\title{
On the Improvement of Accounting Information Quality by Perfecting
}

\author{
Invoice Management \\ Tengfei Chai and GuijiangWen \\ College of Industrial and Administrable Management, Tianjin Polytechnic University \\ Tianjin 300387, China \\ E-mail: tengfeichai@yahoo.com.cn
}

\begin{abstract}
This paper conducts a statistical analysis on the cheating measures adopted in the financial reports of Chinese quoted companies based on relevant information revealed in the punishment proclamations issued by China Securities Regulatory Committee from 2002 to 2008, revealing fictitious transaction as the main cheating measure. In the end, some countermeasures are put forward.
\end{abstract}

Keywords: Quoted companies, Cheating measures, Statistical analysis, Invoice Management

Our modern society of knowledge economy will not do without information, therefore, the quality of accounting information seems particularly important due to its significance in the national economy information system. With this issue having been a hot issue in theoretical researches on accounting, a recent series of deceptive information in accounting have further enhance people's attention to it. Currently, the quality of accounting information has become a significant issue for the accounting profession over the world. It is well known that invoices, one of the original evidences in accounting calculation, will lead to deceptive information if fake or not made out at all, hence spoiling the reliability of the accounting material. Providing fake financial information, false accounts serve as a double-edged sword: on one hand, it damages the interests of the receptor (shareholders, creditors, potential investors and so on); on the other hand, they have also been cheated because the false information will cause a disorder in their internal information systems and hence disturb their decisions. Therefore, based on some relevant information revealed in the punishment proclamations issued by China Securities Regulatory Committee from 2002 to 2008, this paper aims at having a descriptive statistics on the cheating measures adopted by some quoted companies in their financial reports and offering some evidences for the improvement of accounting information by taking some measures in invoice management.

\section{Literary Overview}

After studying the relationship between ownership structure and surplus information quality in 977 companies in East Asia, Joseph P. H. Fan and T. J. Wong (2002) found that the integrated ownership structure as well as the share structure with pyramid pose and cross holdings might lead to agency conflicts between majority shareholders and minority ones. On behalf of their own interests, majority shareholders expose accounting information, which has no reliability in the eyes of those minority ones. Anderson, Deli and Gillan (2003) also found from their empirical research on 1200 American quoted companies in 2001 that independent board of directors might cause increased surplus information, so might the divided posts of chairman of the board and CEO, proving the significance of the board in guaranteeing surplus value relevance. Howe (1999) proved that the violation against GAAP was an inevitable choice in conformity with the cost-profit principle when the administration needed to report higher achievements than their actual ones while they failed to accomplish their target profits even by adopting accounting policies. According to US Treadway Committee (1987), the condition of advanced supervisors, corporate environment and the culture of financial report compilation are the most important elements in the reliability of financial reports. In spite of a set of written regulations and procedures, the loose condition of managers will more probably lead to cheating in financial reports. Feng Liu (2001) claimed that current institutional arrangement was in disagreement with high-quality accounting information and optimized the illegal distortion of accounting information. More relevant legal institutions, instead of only the Accounting Law and corresponding accounting technical standards, should be relied on to solve this problem. In the current institutional environment, it is impractical to wish quoted companies to improve their accounting information and to provide true and reliable information. Jinghua Ma (2005) held that the development of accounting technologies had affirmative and negative effects on the quality of accounting information.

It can be found out from the literature about the researches on improving accounting information quality home and 
abroad that both normative and empirical researches have been conducted involving accounting standards, enterprises' supervision structure, accounting techniques, professional ethics in accounting and so on, which offer theoretical basis and research methods for the improvement of accounting information quality in China.

\section{Selection of Samples}

Here, the sample companies are all those whose cheating actions have been revealed. Two types of frauds in financial report cannot be the object of our research: one is the undetected cheating actions; the other is the detected but unpublicized ones due to some remedial measures conducted within their companies (Kaminski et al, 2004). In this paper, the punishment proclamations issued by China Securities Regulatory Committee from 2002 to 2008 are based on to select samples because these cases are quite typical and representative due to their wide influences over the whole nation and their actions verified by China Securities Regulatory Committee to be frauds instead of mistakes. Those financial reports which are being investigated but haven't been punished and those which have no serious effects are not included in this research. According to the purpose of our research, we sorted out the punished companies during the period as follows: (1) rejecting those companies who have been punished due to their failure to disclose their periodic reports on time or their frauds in capital rating; (2) making every company a different sample who has been punished several times; (3) rejecting illegal transaction, undisclosed information (including illegal transaction, guarantee, connected transaction, prescription and so on), delayed disclosure and fictitious disclosure of the use of funds while only taking the disclosure of fictitious management achievements intended to add some colors to financial reports with capital and profit padding into consideration. Thus, we finally got 55 samples of fictitious financial reports: 9 samples in 2002, 7 ones in 2003, 13 ones in 2004, 5 ones in 2005, 6 ones in 2006, 7 ones in 2007 and 8 in 2008.

\section{Statistical Analysis and Its Result}

The result of the data analysis on the sample companies is shown in Table 1.

A common characteristic can be found in the 55 sample companies' cheating methods: the most extensively-employed method is "fabricating transactions (using fictitious invoices)", which is employed by 25 among the 55 samples, taking up $45.5 \%$. They fabricate their sales income and profits by fabricating transactions and invoices. For those enterprises with a large volume and a wide range of business, this method will enable them to increase profits effectively and therefore is frequently employed.

\section{Conclusions and Suggestions}

The following conclusions can be drawn from the above analysis: quoted companies mainly conduct income frauds, especially increasing their income with fictitious invoices.

Accordingly, here are three countermeasures:

\subsection{Establishing Strict Invoice Management Regulations}

China's Criminal Law lays down different punishments for crimes in plain invoices and VAT invoices. Currently, with the perfect management of VAT invoices, enterprises and individuals have shifted their attention to plain ones, leading to extensive use of fictitious invoices nowadays. Therefore, some articles in Criminal Law have to be amended to strictly strike the crimes in using plain invoices like what was done before on the crimes in VAT invoices due to the vicious and serious nature and bad influence of printing, selling at a profit and buying plain invoices illegally. Only by enhancing the punishment on them will these illegal actions be restricted and China's accounting information quality be really improved.

\subsection{Establishing Unified Invoice Management Institution}

In order to enhance invoice management, a highly-unified and authoritative Invoice Management institution must be established to conduct their administrative duties in invoices and similar bills. Among the three administration departments, Ministry of Finance and local financial departments at all levels are expected to serve as a lead to establish Invoice Management institutions and national tax as well as local tax departments should conduct Invoice Management in an all-round way. Their main duties include: first, seriously striking illegal crimes such as fabricating, buying and selling invoices at a profit and breaking off the source of illegal invoices; second, conducting serious audit on drawing, issuing and cancelling all invoices to avoid the illegal use of legal invoices and bills; third, further conducting serious administration on VAT with the administrative regulations on VAT invoices and having tracking monitor on general tax-payers by having a network hookup with the national tax department; fourth, having regular check on all invoices involved in enterprises' finance and making greater efforts to investigate and deal with illegal invoices. The business department, the public security department, the audit department as well as the procuratorate and court are expected to have consolidated efforts to administrate the invoice market and strike relevant crimes.

\subsection{Further Enhancing Interest-oriented Guidance System of Invoice Management}

In those industries with larger proportions of individual consumption and cash consumption, a variety of 
scratch-and-win receipts should be introduced; reasonable ways should be designed according to consumers' psychology to increase the chances of winning; reasonable rewards should be given and the rewards-disclosed cycle should be designed in a scientific way; rewards should be given timely to encourage consumers to ask for invoices themselves; a reward system on reporting violations against invoice regulations should be conducted to fully encourage as many consumers as possible to be involved in monitoring invoices, hence increasing the effectiveness of Invoice Management.

\section{References}

Anderson, Kirsten L., Deli, Daniel N., \& Gillan, Stuart L. (2003). Boards of Directors, Audit Committees and the Information Content of Earnings. Working Paper.

Dong, Huiyi. (2003). A Discussion on Some Issues in Accounting Information Disclosure. Ningxia Accounting, (10).

Fan, Joseph P.H., \& Wong, T.J.. (2002). Corporate ownership Structure and the Informativeness of Accounting Earnings in East Asia. Journal of Accounting and Economies, (33): pp401-425.

Hwoe, M.A. (1999). Management Fraud and Earnings Management: Fraud Versus GAAP as a Means to Increase Reported Income (Ph.D.dissertation). University of Conneticut, $\mathrm{p} 45$.

Kathleen, A. K., Sterling, T. W., \& Liming, G. (2004). Can Financial Ratios Detect Fraudulent Financial Reporting? Managerial Auditing Journal, 19(1): pp15-28.

Li, Maosheng., \& Yuan, Dejun. (2003). A Report of Problems in Chinese Stock Market. Beijing: China Social Sciences Press.

Liu, Feng. (2001). Institutional Arrangement and Accounting Information Quality. Accounting Research, (7).

Ma, Jinghua. (2005). The Influence of the Development of Accounting Technology on Accounting Information Quality (Master's dissertation). Beijing: Capital University of Economics and Business.

Yang, Tao. (2009). Common Financial Cheating Methods Used by Quoted Companies. Journal of Qingqing University of Technology. (7): pp28-31.

Zhu, Jinyu., \& Gao, Shansheng. (2007). Fictitious Financial Reports of Quoted Companies and Relevant Prevention and Monitor: An Analysis Based on the Punishment Proclamations of China Securities Regulatory Committee. Accounting Research. (11): pp17-23. 
Table 1. The classification of the sample companies' main cheating methods

\begin{tabular}{|c|c|c|c|}
\hline \multirow{26}{*}{$\begin{array}{l}\text { Disclosure of } \\
\text { fictitious } \\
\text { management } \\
\text { achievements }\end{array}$} & Cheating methods & $\begin{array}{r}\text { Number of sample } \\
\text { companies }\end{array}$ & $\begin{array}{r}\text { Percentage } \\
(\%)\end{array}$ \\
\hline & $\begin{array}{l}\text { Fabricating transactions (using } \\
\text { fictitious invoices) }\end{array}$ & 25 & 45.5 \\
\hline & Understating allowance & 13 & 23.6 \\
\hline & Understating allowance for bad debt & 13 & 23.6 \\
\hline & Pre-affirming income & 10 & 18.2 \\
\hline & $\begin{array}{l}\text { Increasing or fabricating bank } \\
\text { deposits }\end{array}$ & 8 & 14.5 \\
\hline & $\begin{array}{l}\text { Increasing or fabricating investment } \\
\text { profits }\end{array}$ & 8 & 14.5 \\
\hline & $\begin{array}{l}\text { Fabricating the recovery of accounts } \\
\text { receivable }\end{array}$ & 5 & 9.1 \\
\hline & Understating debt & 5 & 9.1 \\
\hline & Fabricating projects in construction & 5 & 9.1 \\
\hline & Carrying forward understated cost & 5 & 9.1 \\
\hline & Improper consolidated statement & 4 & 7.3 \\
\hline & Fabricating stock & 3 & 5.5 \\
\hline & Capitalizing expenses & 3 & 5.5 \\
\hline & Employing interrelated deal & 3 & 5.5 \\
\hline & Fabricating overseas investment & 2 & 3.6 \\
\hline & Changing accounting policies & 2 & 3.6 \\
\hline & $\begin{array}{l}\text { Not Amortizing equity investment } \\
\text { difference }\end{array}$ & 2 & 3.6 \\
\hline & deferred affirming expenses & 2 & 3.6 \\
\hline & Increasing prepayment & 2 & 3.6 \\
\hline & $\begin{array}{l}\text { Increasing or fabricating invisible } \\
\text { capital }\end{array}$ & 1 & 1.8 \\
\hline & $\begin{array}{l}\text { Understating impairment provisions } \\
\text { for fixed assets }\end{array}$ & 1 & 1.8 \\
\hline & $\begin{array}{l}\text { Fabricating Non-operating income } \\
\text { into operating one }\end{array}$ & 1 & 1.8 \\
\hline & $\begin{array}{l}\text { Increasing short-term investment } \\
\text { value }\end{array}$ & 1 & 1.8 \\
\hline & Increasing non-distributed profits & 1 & 1.8 \\
\hline & $\begin{array}{l}\text { Writing off the expenses in the } \\
\text { current period with windfall profit }\end{array}$ & 1 & 1.8 \\
\hline
\end{tabular}

These data come from http://www.csrc.gov.cn 